\title{
Evaluation of Aluminum Cans As A Thermal Insulator in Reinforced Concrete Slabs
}

\author{
Laith K. I. Al-Taie,
}

Civil Engineering Department, University of Mosul

\begin{abstract}
Thermal insulation is the most effective energy efficient technique of energy conservation available today. The main goal of energy an conscious designer is to condition the interior environment to support a level of climate comfort acceptable to users. From the past 20 years data it is concluded that temperature is at the increase and thus thermal insulation is an immediate need to be considered. Environmental problems have recently expanded due to industrial pollution and manmade products that are found in solid wastes. One of these products are the Aluminum cans. Since the recycling rate of these cans is decreasing. It is therefore the main goal of this study is to evaluate the thermal insulation of these cans through models in insulating reinforced concrete roofs and ceiling and comparing the insulation with that of Thermo-stone blocks and Polystyrene boards which are commonly used in Iraq. Results indicated that Aluminum cans are considered as a good insulator and can withstand a considerable live and dead loads beside it's low construction cost and low weight. Finally the use of Aluminum cans in the thermal insulation will contribute in solving a part of the global environmental problems.
\end{abstract}

Keywords: Thermal Insulation, Solid wastes, Aluminum cans, Model.

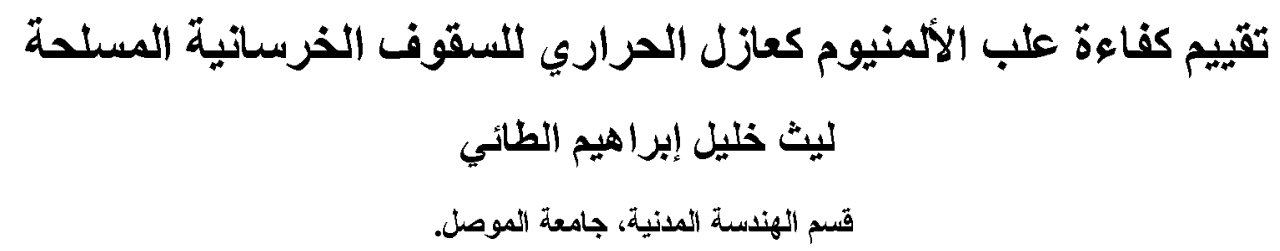

\footnotetext{
الخلاصة

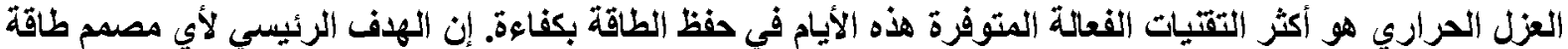

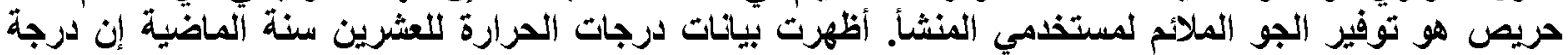

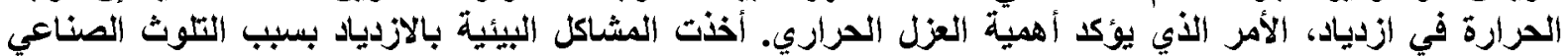

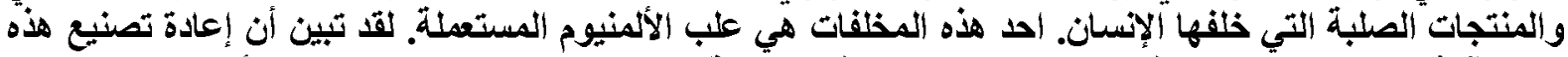

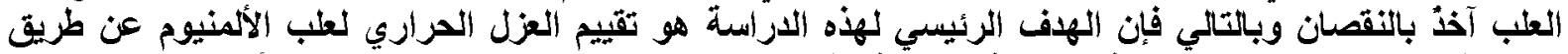

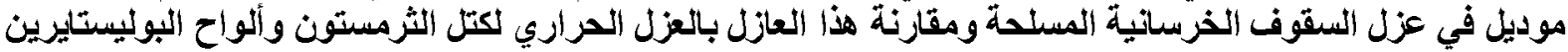

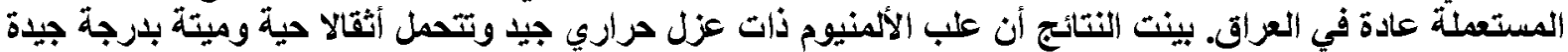

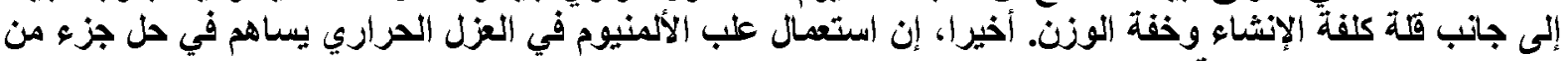
مشاكل التلوث العالمي للبيئة.
} 


\begin{tabular}{|c|c|c|}
\hline Notations & & Unit \\
\hline $\mathbf{Q}$ & Heat Flow & $\mathrm{W}$ \\
\hline $\mathbf{T}_{1}-\mathbf{T}_{2}$ & Thermal potential gradient & ${ }^{\circ} \mathrm{C}$ \\
\hline $\mathbf{L}$ & Material thickness & $\mathrm{m}$ \\
\hline $\mathbf{A}$ & Area & $\mathrm{m}^{2}$ \\
\hline $\mathbf{k}$ & Thermal conductivity & $\mathrm{w} / \mathrm{m} .{ }^{\circ} \mathrm{C}$ \\
\hline $\mathbf{R}$ & Thermal resistance & ${ }^{\mathrm{o}} \mathrm{C} / \mathrm{w}$ \\
\hline $\mathbf{R t}$ & Overall thermal resistance & ${ }^{\circ} \mathrm{C} / \mathrm{w}$ \\
\hline $\mathbf{A C}$ & Aluminum cans & \\
\hline TB & Thermo-stone Blocks & \\
\hline PB & Polystyrene Boards & \\
\hline Model A & Model with insulation & \\
\hline Model B & Model without insulation & \\
\hline $\mathbf{T}_{1}$ & Temperature reading at the surface of the tile. & ${ }^{\circ} \mathrm{C}$ \\
\hline $\mathbf{T}_{2}$ & Temperature reading at the lower face of the reinforced concrete slab. & ${ }^{\circ} \mathrm{C}$ \\
\hline $\mathbf{T}_{3}$ & Temperature reading of the inner air space of the model. & ${ }^{\circ} \mathrm{C}$ \\
\hline$\Delta \mathbf{T}_{1 \mathrm{a}}$ & Temperature gradient of model $\mathrm{A}, \Delta \mathrm{T}_{1 \mathrm{a}}=\mathrm{T}_{1}-\mathrm{T}_{2}$ & ${ }^{\circ} \mathrm{C}$ \\
\hline$\Delta \mathbf{T}_{2 \mathbf{a}}$ & Temperature gradient of model $\mathrm{A}, \Delta \mathrm{T}_{2 \mathrm{a}}=\mathrm{T}_{1}-\mathrm{T}_{3}$ & ${ }^{\circ} \mathrm{C}$ \\
\hline$\Delta \mathbf{T}_{1 \mathrm{~b}}$ & Temperature gradient of model $\mathrm{B}, \Delta \mathrm{T}_{1 \mathrm{~b}}=\mathrm{T}_{1}-\mathrm{T}_{2}$ & ${ }^{\circ} \mathrm{C}$ \\
\hline$\Delta \mathbf{T}_{\mathbf{2 b}}$ & Temperature gradient of model $\mathrm{B}, \Delta \mathrm{T}_{2 \mathrm{~b}}=\mathrm{T}_{1}-\mathrm{T}_{3}$ & ${ }^{\circ} \mathrm{C}$ \\
\hline$\Delta$ Net $_{1}$ & Temperature gradient, $\Delta \mathrm{Net}_{1}=\Delta \mathrm{T}_{1 \mathrm{a}}-\Delta \mathrm{T}_{1 \mathrm{~b}}$ & ${ }^{\circ} \mathrm{C}$ \\
\hline$\Delta \mathbf{N e t}_{2}$ & Temperature gradient, $\Delta \mathrm{Net}_{2}=\Delta \mathrm{T}_{2 \mathrm{a}}-\Delta \mathrm{T}_{2 \mathrm{~b}}$ & ${ }^{\circ} \mathrm{C}$ \\
\hline
\end{tabular}

\section{Introduction:}

Thermal insulation is the most effective technique of energy conservation available today. Thermal insulation has the largest impact on reducing fuel cost year after year. The main goal of an energy conscious designer is to condition the interior environment to support a level of climate comfort acceptable to users. Efficient use of energy is important since global energy resources are finite and power generation using fossil fuels (such as coal and oil) has adverse environmental effects. Thermal insulation is a technique that minimizes the transfer of heat energy from inside to outside and vice versa, of a building by reducing the conduction, convection and radiation effects. From the previous on-going 20 years data it is found that the temperature is increasing and thus thermal insulation is an immediate need to be considered for occupant comfort [1], [2].

Environmental problems have recently expanded due to industrial pollution and also due to man made products that are found in solid wastes. One of these materials are the used Aluminum cans. Since 1972, some 594 billion used Aluminum cans have been recycled. If these cans are placed end to end, this would stretch to the moon and back 190 times. Of the 102 billion Aluminum can manufactured in 1999, 63.8 billion of them were recycled. Unfortunately, recycling rate was noticed to be decreasing specially since 1992 (figure 1) [3], [4]. As it is known that these cans are manufactured from aluminum, aluminum is the most abundant metallic element in the earth's crust and, after oxygen and silicon, by mass the third most abundant of all elements in the earth's crust. It constitutes approximately $8 \%$ of the earth's crust by mass [4], [5].

There are various thermal insulating materials, commonly used are flexible (mineral wool, glass fiber), loose fill, and spray. In Iraq, the most common insulating materials are Thermostone blocks, Polystyrene boards and air gap (Cavity) [6], [7]. 
Al-Taie: Evaluation of Aluminum Cans As A Thermal Insulator

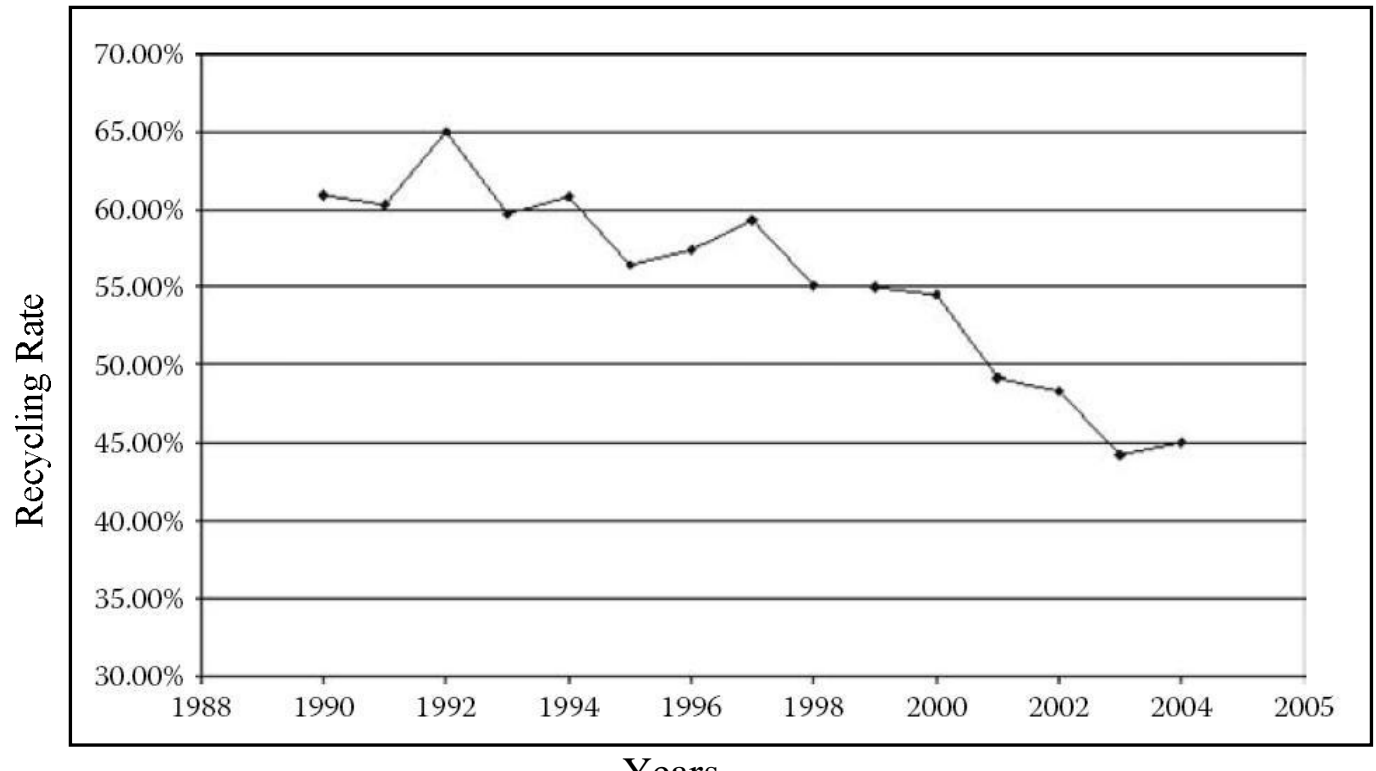

Figure (1): U.S. aluminum recycling rates from 1990 to 2004 (Container Recycling Institute, n.d.), after M. E. Schlesinger.

Insulation material are evaluated in many methods, the most common are U-value and Rvalue. U-value is the measurement of heat flow, the lower the U-value the better the thermal insulation. R-value is another mathematical expression used to quantify an insulation agent. It indicate the resistance to heat flow. The higher the R-value, the greater insulation effectiveness [8], [9]. In general:

$Q=\frac{T_{1}-T_{2}}{R}$

$R=\frac{L}{A \cdot k}$

Where:

Q: Heat flow (w)

$\mathrm{T}_{1}-\mathrm{T}_{2}$ : Thermal potential gradient $\left({ }^{\circ} \mathrm{C}\right)$.

L: Material thickness (m)

A: Area $\left(\mathrm{m}^{2}\right)$

$\mathrm{k}$ : Thermal conductivity $\left(\mathrm{w} / \mathrm{m} .{ }^{\circ} \mathrm{C}\right)$

$\mathrm{R}$ : Thermal resistance $\left({ }^{\circ} \mathrm{C} / \mathrm{w}\right)$

In many engineering applications, heat transfer takes place through a medium composed of several different layers, each having a different thermal conductivity, $\mathrm{k}$. for composite slabs the heat flow:

$Q=\frac{T_{a}-T_{b}}{R}$

$R t=R_{a}+R_{1}+R_{2}+\cdots+R_{b}$

Where:

Rt: Overall thermal resistance 
The main goal of this study is to evaluate the thermal insulation of used Aluminum cans in insulating reinforced concrete roofs and ceilings and comparing the insulation efficiency with Thermo-stone blocks and Polystyrene boards that are commonly used in Iraq for slabs thermal insulation. The comparison between the selected insulation materials will be based on four aspects, temperature gradient, compressive strength, weight and cost.

\section{Materials and Methods:}

In order to accomplish the project goals, two identical models were built from local construction materials used in Iraq, this will idealy represent the local boundary conditions of the studied area. The construction site was selected to insure direct sun light on the model ceiling during the day. The site was located in Iraq, Mosul city $\left(36^{\circ} 23^{\prime} 35.41^{\prime \prime} \mathrm{N}\right.$ and $43^{\circ} 08^{\prime}$ 38.18" E, elevation: $258 \mathrm{~m}$ from MSL, Google Earth 2009). One of the models was insulated and the other was kept without insulation to be taken as a reference or as a benchmark.

The construction materials of the two models consisted of a reinforced concrete slab $(100 \times 100 x 15) \mathrm{cm}$ supported by four brick walls of (12)cm thickness and (100)cm height, the four walls were insulated with a clay rendering of $(2.5) \mathrm{cm}$ thickness then the last was covered with a (5) $\mathrm{cm}$ PB, table (1). The floor was also insulated using a (5) $\mathrm{cm}$ dry clay layer covered with Styrofoam board of (5) $\mathrm{cm}$ thickness. This procedure was adopted to minimize the heat that would come from the walls and the roof, table (1), figure (2). The reinforced concrete slab was simulated to the local slabs manufactured in Iraq. Usually the slabs in Iraq are covered with tiles that are mostly of white color. The slabs of the two models were covered with tiles plus a cement mortar of (3) cm thick beneath (the insulating agent was installed beneath the tile mortar for the insulated model).

\begin{tabular}{|c|c|c|}
\hline \multicolumn{3}{|c|}{ Table (1): Legend of the materials used in model construction. } \\
\hline Legend & Material & Dimension(s) (cm) \\
\hline & Aluminum cans (AC) & $12.5 \times 6 \varnothing$ \\
\hline & Thermo-stone Blocks (TB) & 5.5 \\
\hline$\because \cdots$ & Polystyrene Boards (PB) & 5 \\
\hline $1,1,1$ & Clay brick & $23 \times 11 \times 7$ \\
\hline & Clay rendering & 5 \\
\hline & Tile & $30 \times 30 \times 15$ \\
\hline & Sand mortar $(1: 3)$ & 3 \\
\hline & Reinforced concrete $(1: 2: 4 / 0.50)$ & $100 \times 100 \times 15$ \\
\hline & Thermometer probe & $2.5 \times 0.5$ \\
\hline
\end{tabular}

Three digital thermometers were used for each model (range -50 to $+70^{\circ} \mathrm{C}, \pm 0.1^{\circ} \mathrm{C}$ accuracy). A thermometer was imbedded in the surface of the tile by making a groove that just fit the thermometer probe which was fixed to the tiles using a white cement paste (almost the same color of the tile). Another thermometer was installed at the lower face of the concrete slab similar to the tile's thermometer probe except using an ordinary cement paste. The last thermometer was hanged at the middle height of the model inner space for reading air temperature inside the model. All thermometers were installed during the construction process of the two models, figure (2).

Three types of insulation materials were used in this project, $\mathrm{AC}, \mathrm{TB}$ and $\mathrm{PB}$. One of the models was treated with insulation (model A) while the other was kept as a reference without insulation (model B). The insulating agent was placed beneath the tiles covering the slab. Each insulation material was tested for one week using the two models. Temperature readings were taken daily at (7:00, 9:00, 11:00, 12:00, 13:00, 14:00, 15:00, 17:00, 19:00 and 21:00), (July-August, 2008). 


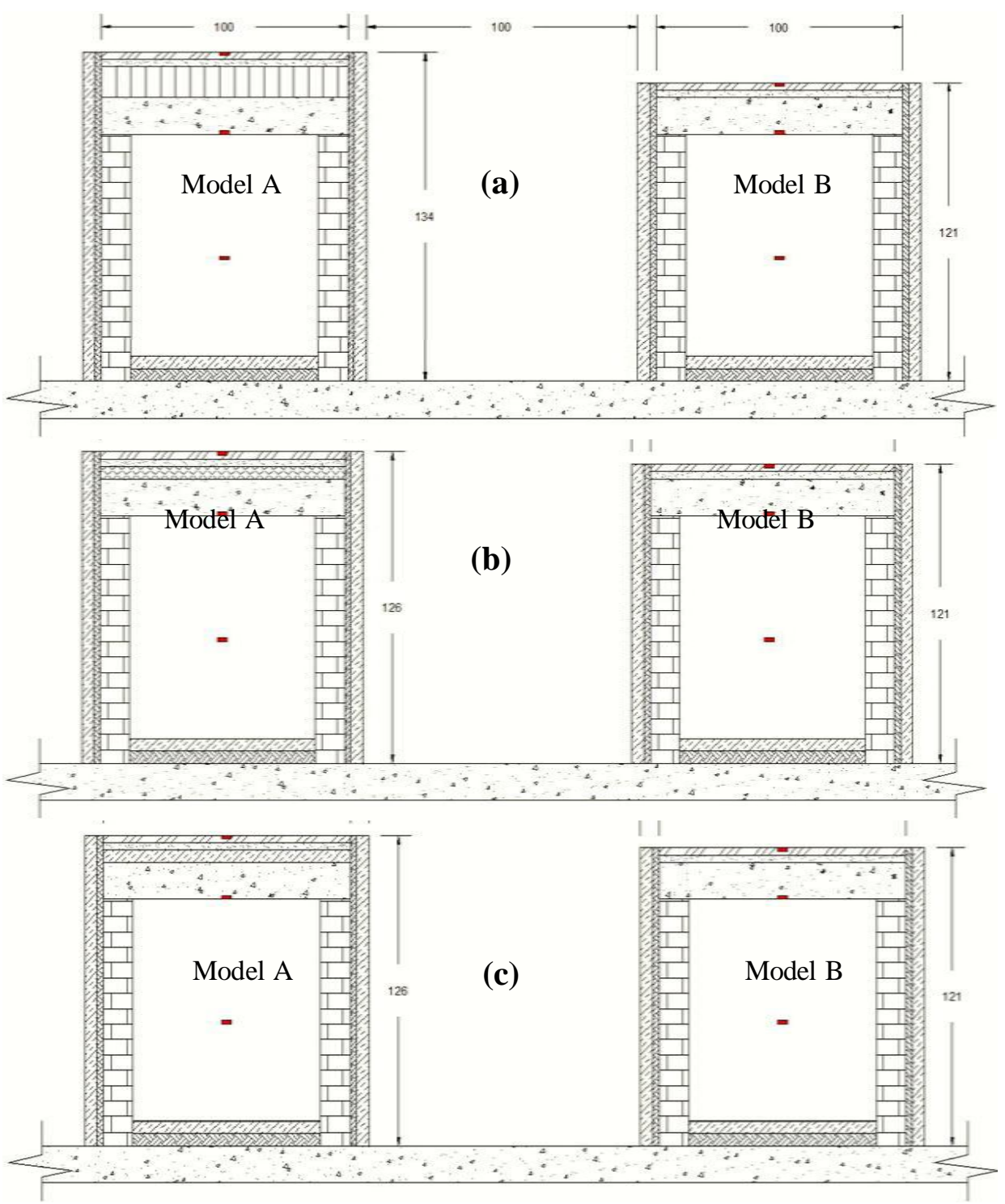

Figure (2): Schematic diagram of Model A and Model B, (a): AC. (b): TB. (c): PB.

The compressive strength of the AC must be obtained. A group of cans were arranged in a hexagonal shape that consists of seven cans, figure (3). Three groups were tested in the unconfined compression machine with a slow rate $(0.35 \mathrm{~mm} / \mathrm{min}$.). A single can was also tested in the same machine with the same loading rate. The compressive strength of TB was taken as referred in the literature

\section{Results and Discussion:}

In order to evaluate which insulation material is better among the selected, the comparison was based on four aspects, temperature gradient, compressive strength, weight and cost. The following paragraphs will discuss these aspects.

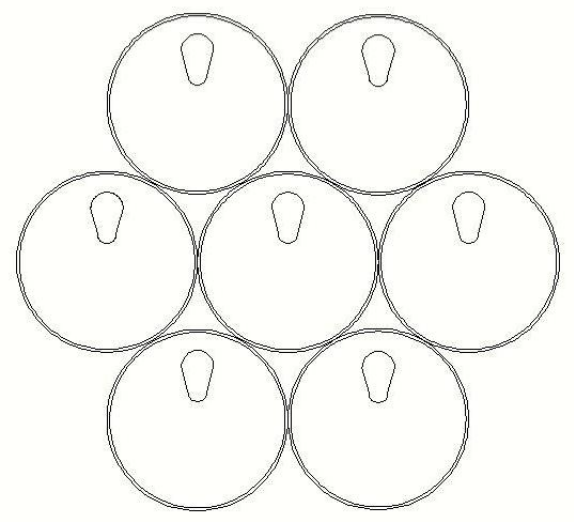

Fig. (3): Hexagonal arrangement of AC for compressive strength evaluation. 


\subsection{Temperature Gradients:}

Temperature readings were taken at the same time for model (A) and model (B). There was a thermal gradient between tile temperature $\left(T_{1}\right)$, concrete slab $\left(T_{2}\right)$ and air space $\left(T_{3}\right)$, this is clear in figures $(4,5,6)$ for $\mathrm{AC}$, TB and $\mathrm{PB}$ respectively. It is obvious from these figures that $\mathrm{T}_{1}$ was higher than $\mathrm{T}_{2}$ and $\mathrm{T}_{3}$ for all insulation materials.

In order to make an accurate comparison, the mean temperatures readings of one week were plotted against time for $\mathrm{T}_{1}, \mathrm{~T}_{2}$ and $\mathrm{T}_{3}$, figures $(7,8,9)$ for $\mathrm{AC}, \mathrm{TB}$ and $\mathrm{PB}$ respectively. The mean maximum temperature recorded of $\left(\mathrm{T}_{1}\right)$ was $\left(52.2,54.4\right.$ and $\left.54.3^{\circ} \mathrm{C}\right)$ for $\mathrm{AC}, \mathrm{TB}$ and $\mathrm{PB}$ respectively.

Temperature gradients between model (A) and model (B) were adopted to show the better insulation. The algebraic gradient was calculated on the basis of the time that corresponds to the maximum $\mathrm{T}_{1}$ reading of model $(\mathrm{A})$, table $(2)$, figures $(10,11,12)$

\section{1 .1 Temperature gradient between $\left(T_{1}\right)$ and $\left(T_{2}\right) ;\left(\Delta T_{1}\right)$ :}

The algebraic difference between $T_{1}$ and $T_{2}$ is equal to $\Delta T_{1}$, table (2). From the data listed, the mean value of $\Delta \mathrm{T}_{1 \mathrm{a}}$ for $\mathrm{AC}$ is $20^{\circ} \mathrm{C}$ while the mean value of $\Delta \mathrm{T}_{1 \mathrm{~b}}$ was $9.6^{\circ} \mathrm{C}$. The algebraic difference between $\Delta \mathrm{T}_{1 \mathrm{a}}$ and $\Delta \mathrm{T}_{1 \mathrm{~b}}$ is equal to $\Delta \mathrm{Net}_{1}$, this value for $\mathrm{AC}$ was equal to $10.4^{\circ} \mathrm{C}$. The value $\Delta \mathrm{Net}_{1}$ was adopted in the comparison among the selected insulation

\begin{tabular}{|c|c|c|c|c|c|c|c|}
\hline \multicolumn{8}{|c|}{ AC data analysis } \\
\hline \multirow[t]{2}{*}{ Day } & \multirow{2}{*}{$\begin{array}{c}\text { Time } \\
\text { (Hours) }\end{array}$} & \multicolumn{2}{|c|}{ Model A } & \multicolumn{2}{|c|}{ Model B } & \multirow[b]{2}{*}{$\begin{array}{c}\Delta \mathrm{Net}_{1} \\
\left({ }^{\circ} \mathrm{C}\right)\end{array}$} & \multirow[b]{2}{*}{$\begin{array}{c}\mathrm{Net}_{2} \\
\left({ }^{\circ} \mathrm{C}\right)\end{array}$} \\
\hline & & $\begin{array}{l}\Delta \mathrm{T}_{1 \mathrm{a}} \\
\left({ }^{\mathbf{0}} \mathrm{C}\right)\end{array}$ & $\begin{array}{l}\Delta \mathbf{T}_{2 \mathrm{a}} \\
\left({ }^{\mathbf{0}} \mathbf{C}\right)\end{array}$ & $\begin{array}{l}\Delta \mathbf{T}_{1 \mathrm{~b}} \\
\left({ }^{\mathbf{0}} \mathbf{C}\right)\end{array}$ & $\begin{array}{l}\Delta \mathbf{T}_{2 b} \\
\left({ }^{\mathbf{0}} \mathbf{C}\right)\end{array}$ & & \\
\hline 1 & $3: 00$ & 20.4 & 22.1 & 10 & 15.2 & 10.4 & 6.9 \\
\hline 2 & $3: 00$ & 20.7 & 24.3 & 10.3 & 16.3 & 10.4 & 8 \\
\hline 3 & $2: 00$ & 21.2 & 22.4 & 9.5 & 14.4 & 11.7 & 8 \\
\hline 4 & $3: 00$ & 18.6 & 19.7 & 8.5 & 10.1 & 10.1 & 9.6 \\
\hline 5 & 3:00 & 19.6 & 20.9 & 9.6 & 14 & 10 & 6.9 \\
\hline 6 & $3: 00$ & 20.2 & 22 & 10.5 & 15.9 & 9.7 & 6.1 \\
\hline 7 & 3:00 & 19.3 & 22 & 9.1 & 14.3 & 10.2 & 7.7 \\
\hline \multicolumn{2}{|c|}{ Mean } & 20.0 & 21.9 & 9.6 & 14.3 & 10.4 & 7.6 \\
\hline \multicolumn{8}{|c|}{ TB data analysis } \\
\hline 1 & $2: 00$ & 17.1 & 20.3 & 10.7 & 14.8 & 6.4 & 7.2 \\
\hline 2 & $2: 00$ & 18.1 & 21 & 9.3 & 15.7 & 8.8 & 7.3 \\
\hline 3 & $2: 00$ & 19 & 21.5 & 11.1 & 16.5 & 7.9 & 7.9 \\
\hline 4 & $2: 00$ & 19.7 & 21.1 & 11.9 & 15.1 & 7.8 & 6.9 \\
\hline 5 & $2: 00$ & 19.2 & 21.1 & 12 & 15.3 & 7.2 & 5.9 \\
\hline 6 & $2: 00$ & 18.6 & 21.4 & 11 & 16 & 7.6 & 7 \\
\hline 7 & $2: 00$ & 19.9 & 20.9 & 12.4 & 16.2 & 7.5 & 6.5 \\
\hline \multicolumn{2}{|c|}{ Mean } & 18.8 & 21.0 & 11.2 & 15.7 & 7.6 & 5.3 \\
\hline \multicolumn{8}{|c|}{ PB data analysis } \\
\hline 1 & $2: 00$ & 18.8 & 19.8 & 11.7 & 15 & 7.1 & 4.8 \\
\hline 2 & $2: 00$ & 19 & 19.7 & 11.4 & 13.6 & 7.6 & 6.1 \\
\hline 3 & $2: 00$ & 17 & 17.8 & 9.5 & 13.3 & 7.5 & 4.5 \\
\hline 4 & $2: 00$ & 18.5 & 19.5 & 11 & 14.8 & 7.5 & 4.7 \\
\hline 5 & $1: 00$ & 18.2 & 19.1 & 11.8 & 14.3 & 6.4 & 4.8 \\
\hline 6 & $1: 00$ & 16.9 & 19.1 & 9.4 & 15.1 & 7.5 & 4 \\
\hline 7 & $1: 00$ & 17.7 & 20 & 10.3 & 15.6 & 7.4 & 4.4 \\
\hline \multicolumn{2}{|c|}{ Mean } & 18.0 & 19.3 & 10.7 & 14.5 & 7.3 & 4.8 \\
\hline
\end{tabular}

materials. The value $\Delta \mathrm{Net}_{1}$ for $\mathrm{TB}$ and $\mathrm{PB}$ were $7.6^{\circ} \mathrm{C}$ and $7.3^{\circ} \mathrm{C}$ respectively. It is clear that the $\mathrm{AC}$ showed a greater value of $\Delta \mathrm{Net}_{1}$ than those for $\mathrm{TB}$ and $\mathrm{PB}$. 

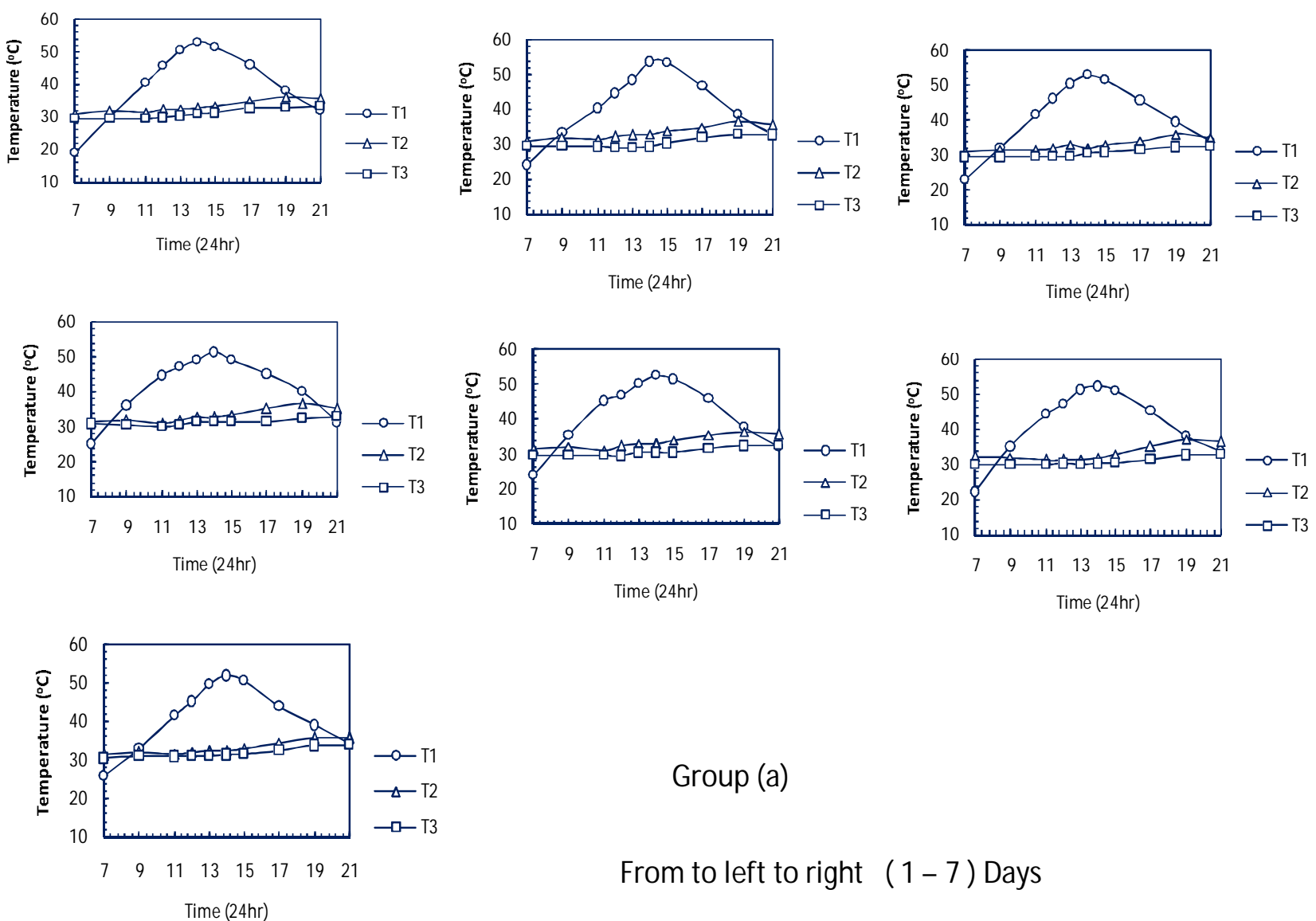

Group (a)

From to left to right ( $1-7$ ) Days
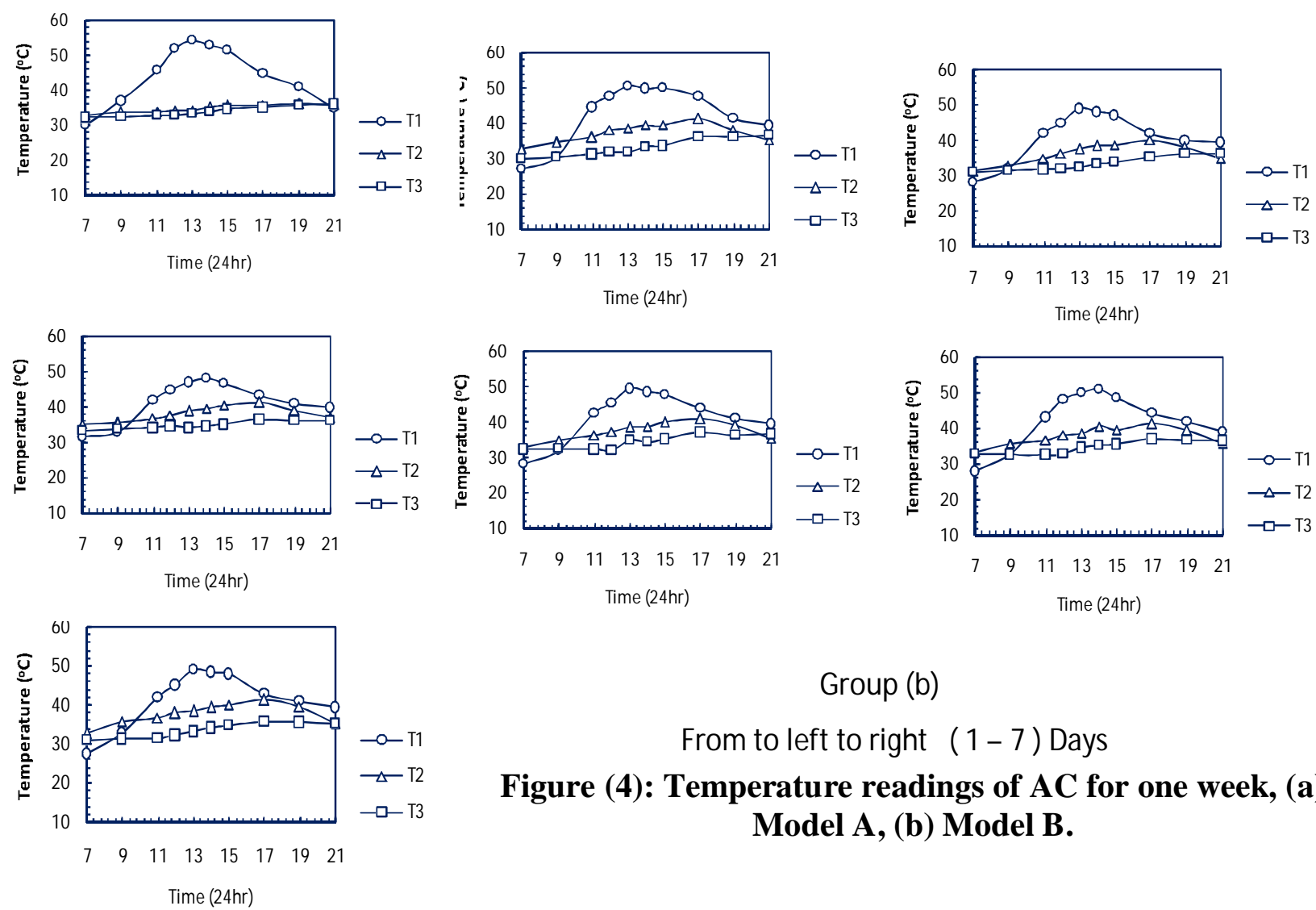

Group (b)

From to left to right ( 1 - 7 ) Days

Figure (4): Temperature readings of $\mathrm{AC}$ for one week, (a) Model A, (b) Model B. 

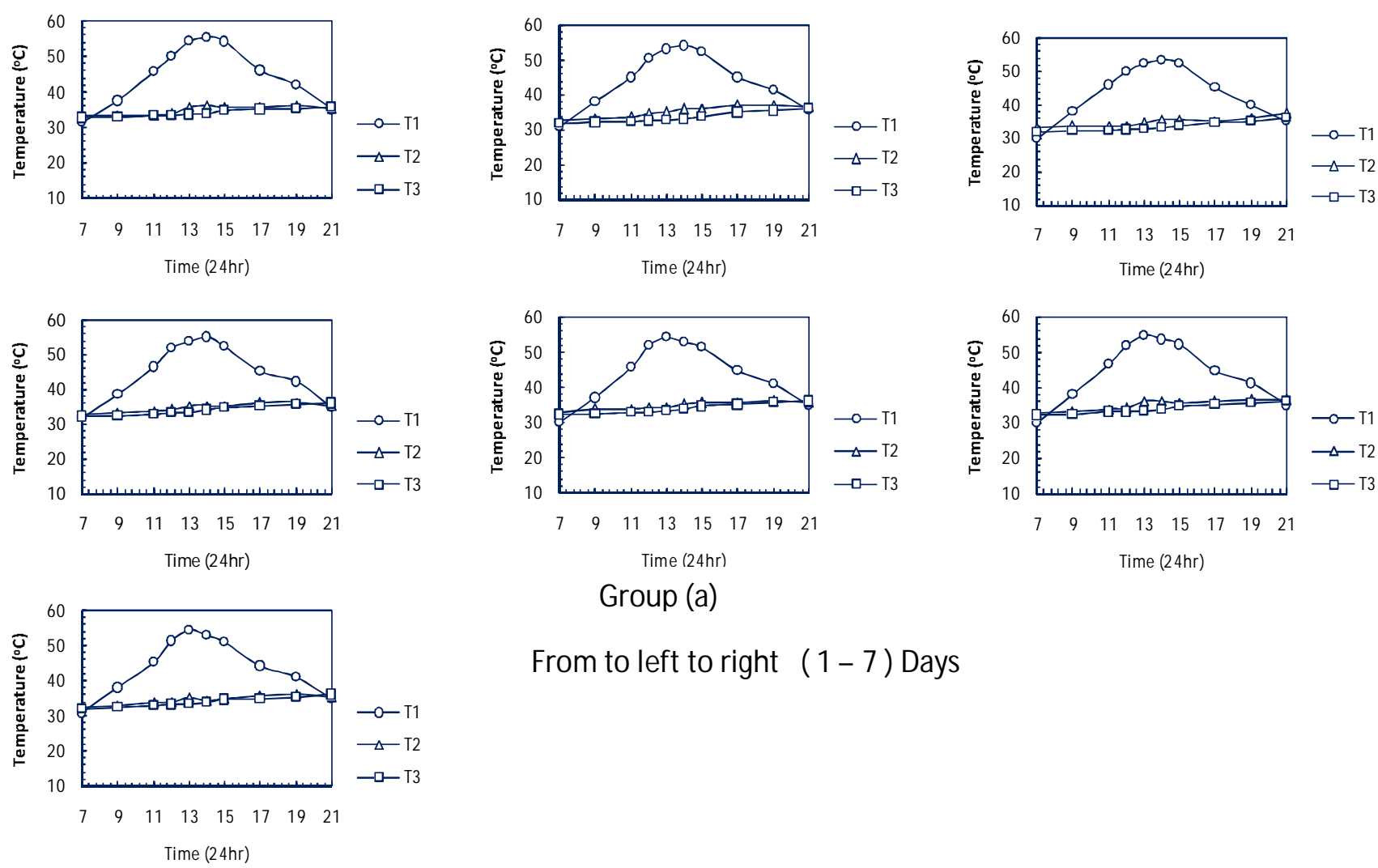

Group (a)

From to left to right ( 1 - 7 ) Days
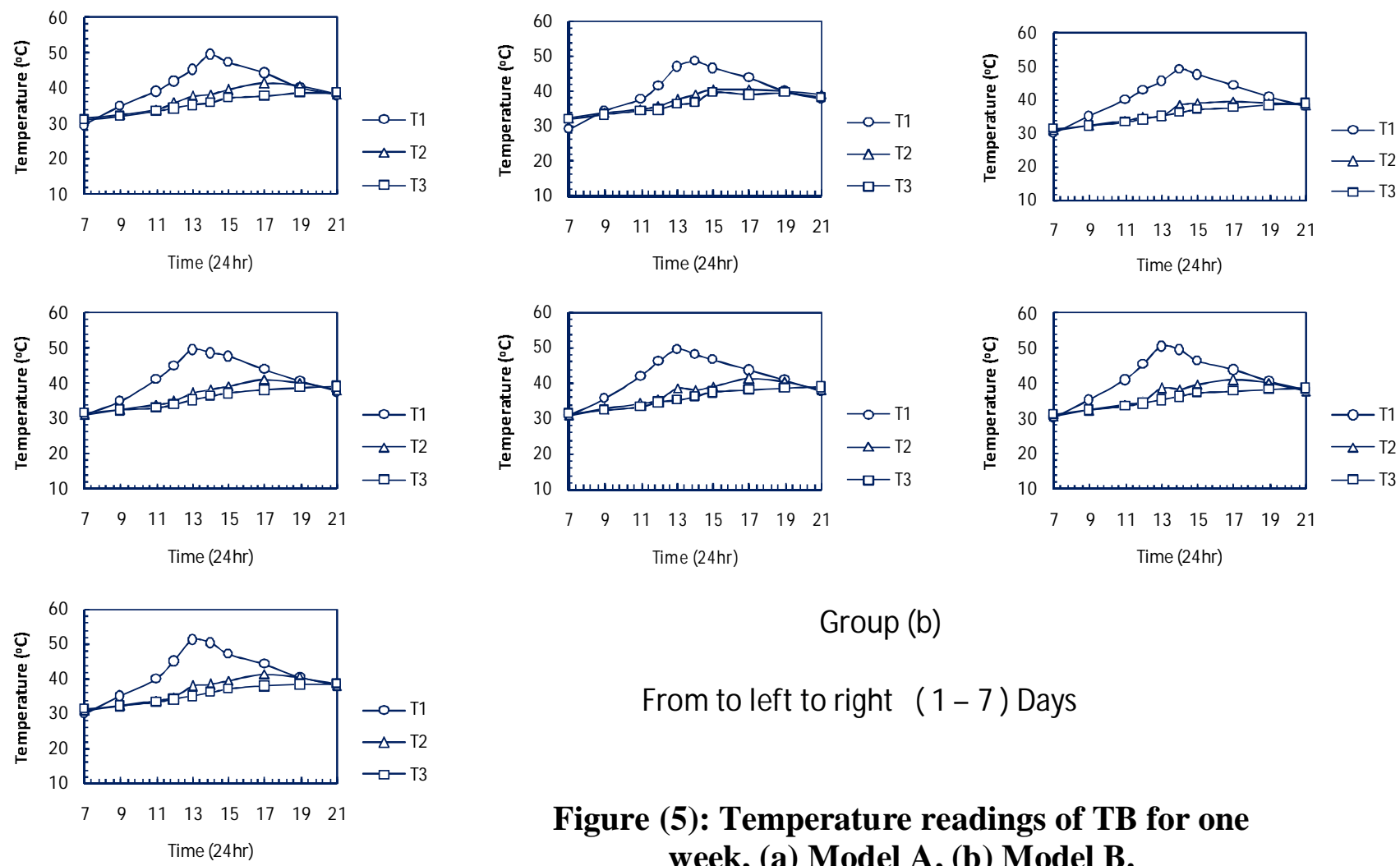

Group (b)

From to left to right ( 1 - 7 ) Days

Figure (5): Temperature readings of TB for one week, (a) Model A, (b) Model B. 

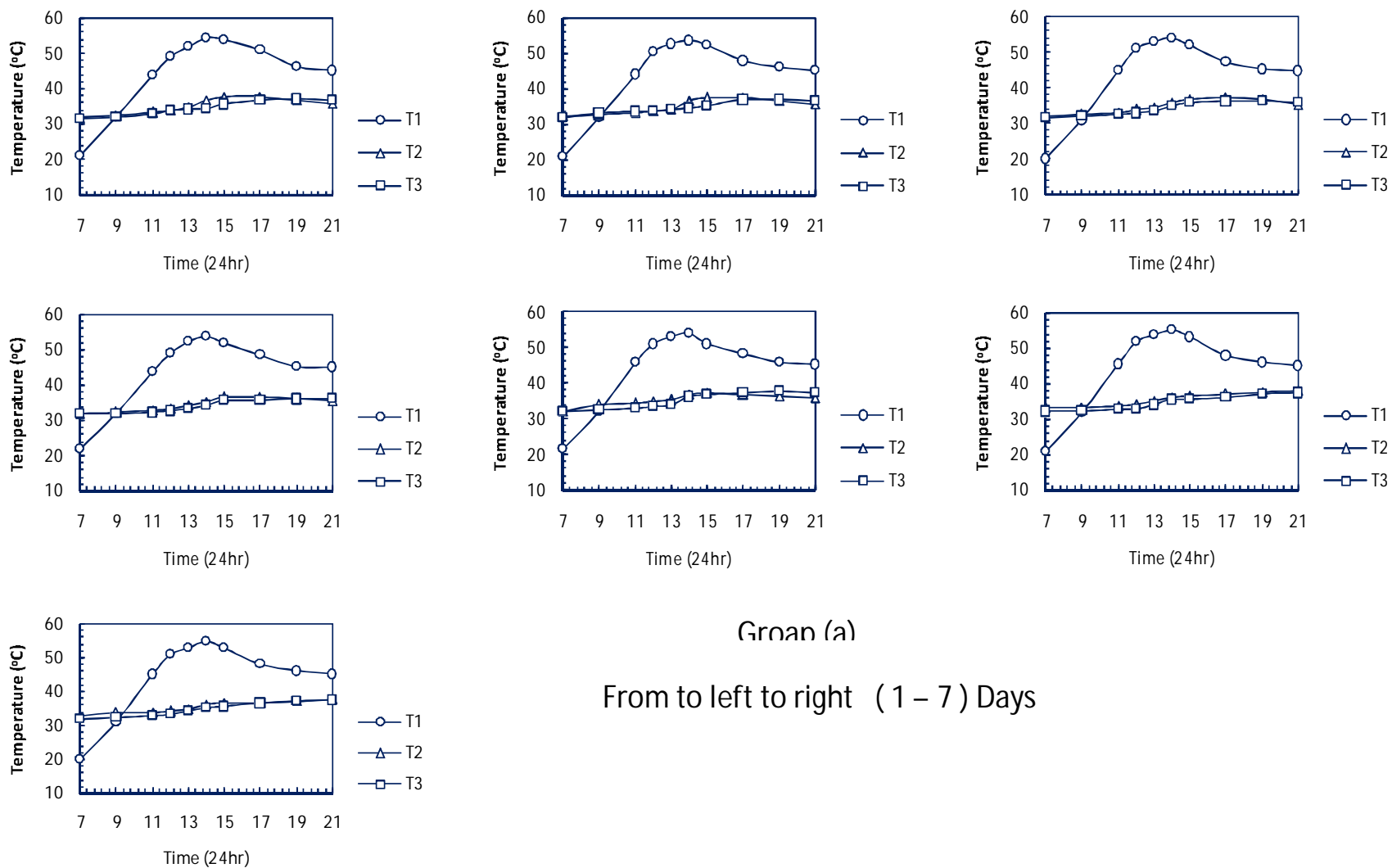

Groan (a)

From to left to right ( $1-7$ ) Days

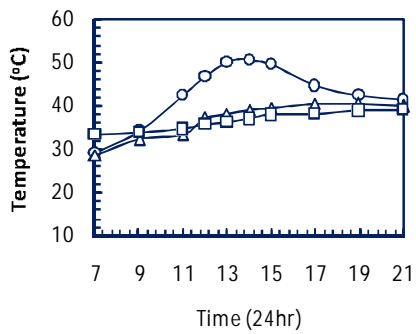

$\longrightarrow \mathrm{T} 1$
$\longrightarrow-\mathrm{T} 2$
$\square-\mathrm{T} 3$
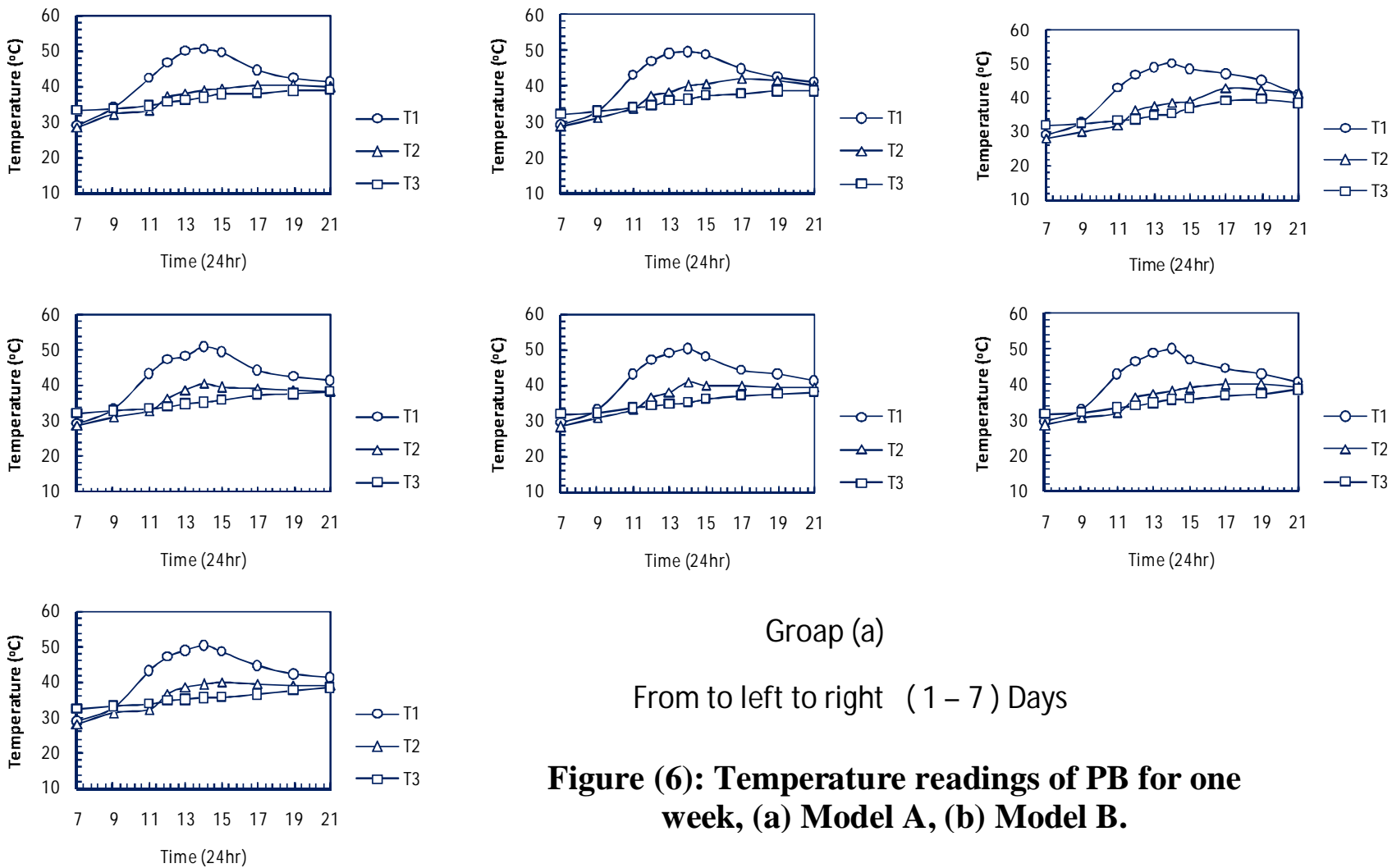

Groap (a)

From to left to right ( $1-7$ ) Days

Figure (6): Temperature readings of $P B$ for one week, (a) Model A, (b) Model B. 


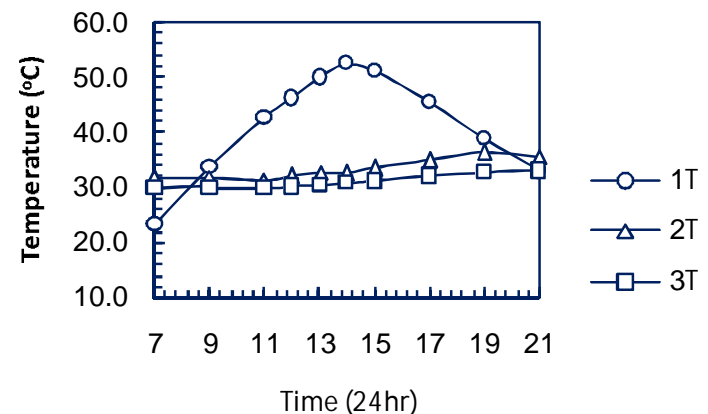

(a)

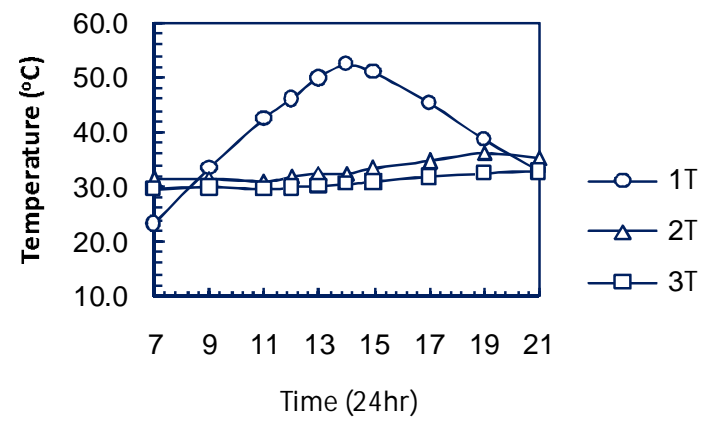

(b)

Figure(7): Mean temperature readings of $\mathrm{AC}$ for one week, (a) $\operatorname{Model} \mathrm{A}$, (b) Model B.

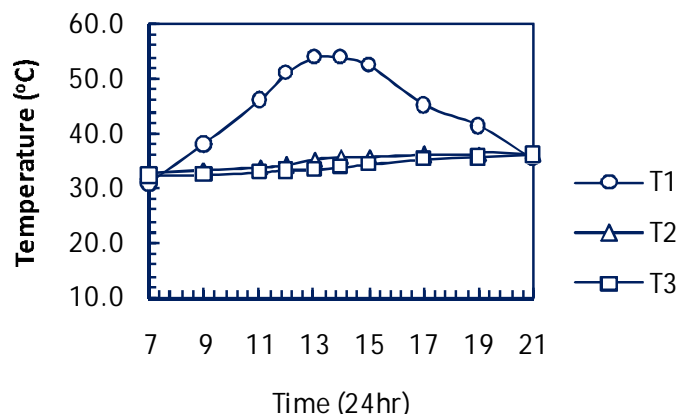

(a)

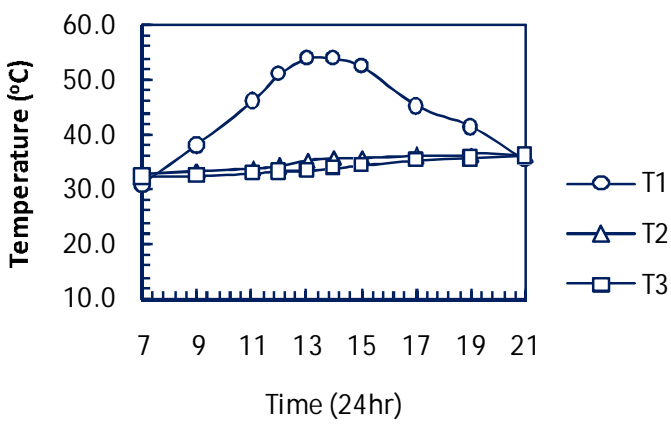

(b)

Figure(8): Mean temperature readings of TB for one week, (a) $\operatorname{Model}$ A, (b) Model B.

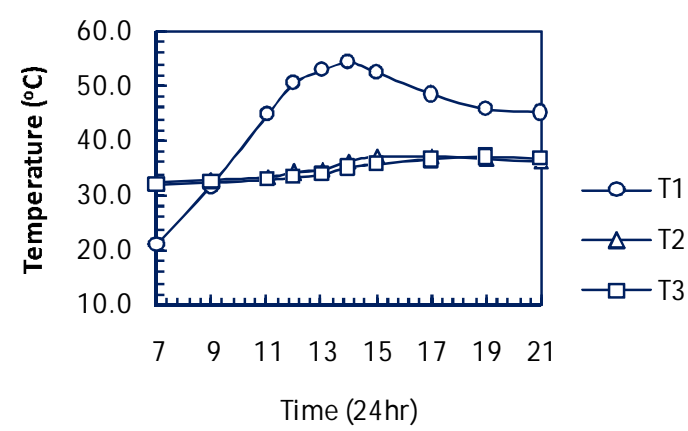

(a)

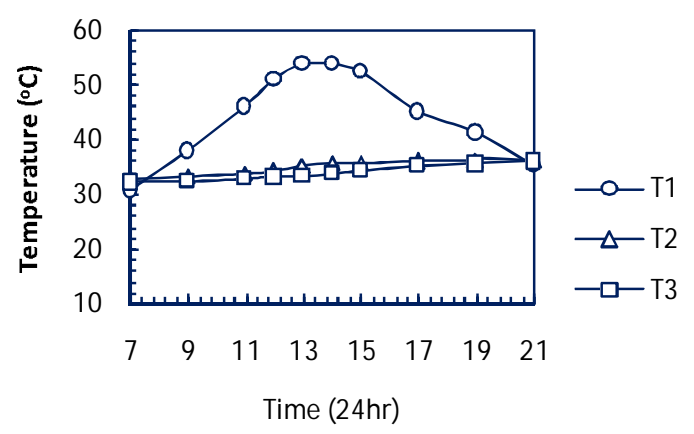

(b)

Figure(9): Mean temperature readings of PB for one week, (a) Model A, (b) Model B. 


\section{1 .2 Temperature gradient between (T1) and (T3); $\left(\Delta T_{2}\right):$}

The same calculation procedure considered in the previous paragraph will be applied here to calculate the gradient between $T_{1}$ and $T_{3}$, this will give $\Delta T_{2}$ value, table (2). The algebraic gradient between $\Delta \mathrm{T}_{2 \mathrm{a}}$ and $\Delta \mathrm{T}_{2 \mathrm{~b}}$ is equal to $\Delta \mathrm{Net}_{2}$ which was considered in the comparison as had used in $\Delta \mathrm{Net}_{1}$ values. The mean value of $\Delta \mathrm{Net}_{2}$ for $\mathrm{AC}$ is $7.6^{\circ} \mathrm{C}$, while it is $5.3^{\circ} \mathrm{C}$ and $4.8^{\circ} \mathrm{C}$ for TB and $\mathrm{PB}$ respectively.

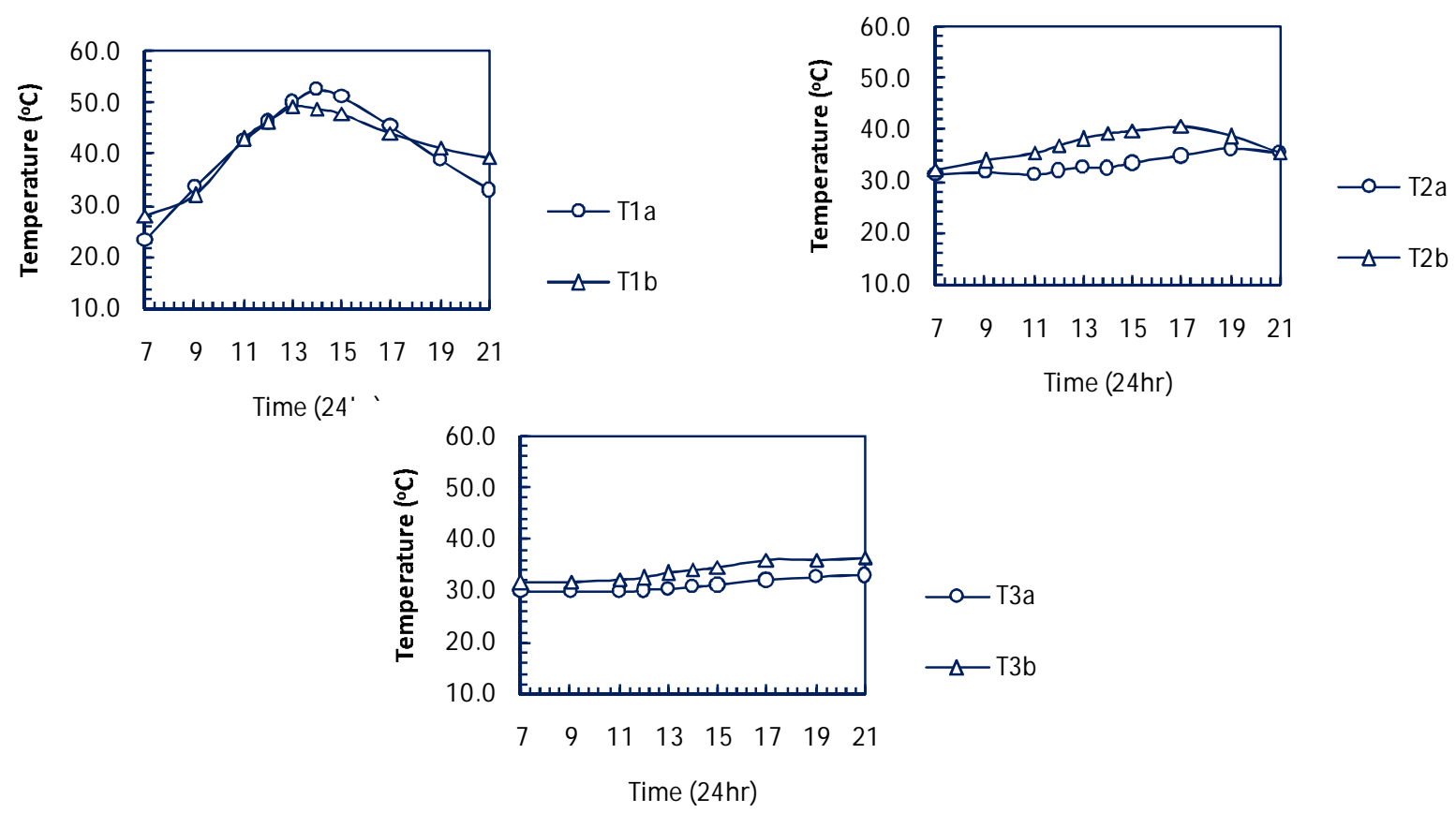

Figure (10): Comparison between mean temperature readings of model $A$ and Model B for AC.

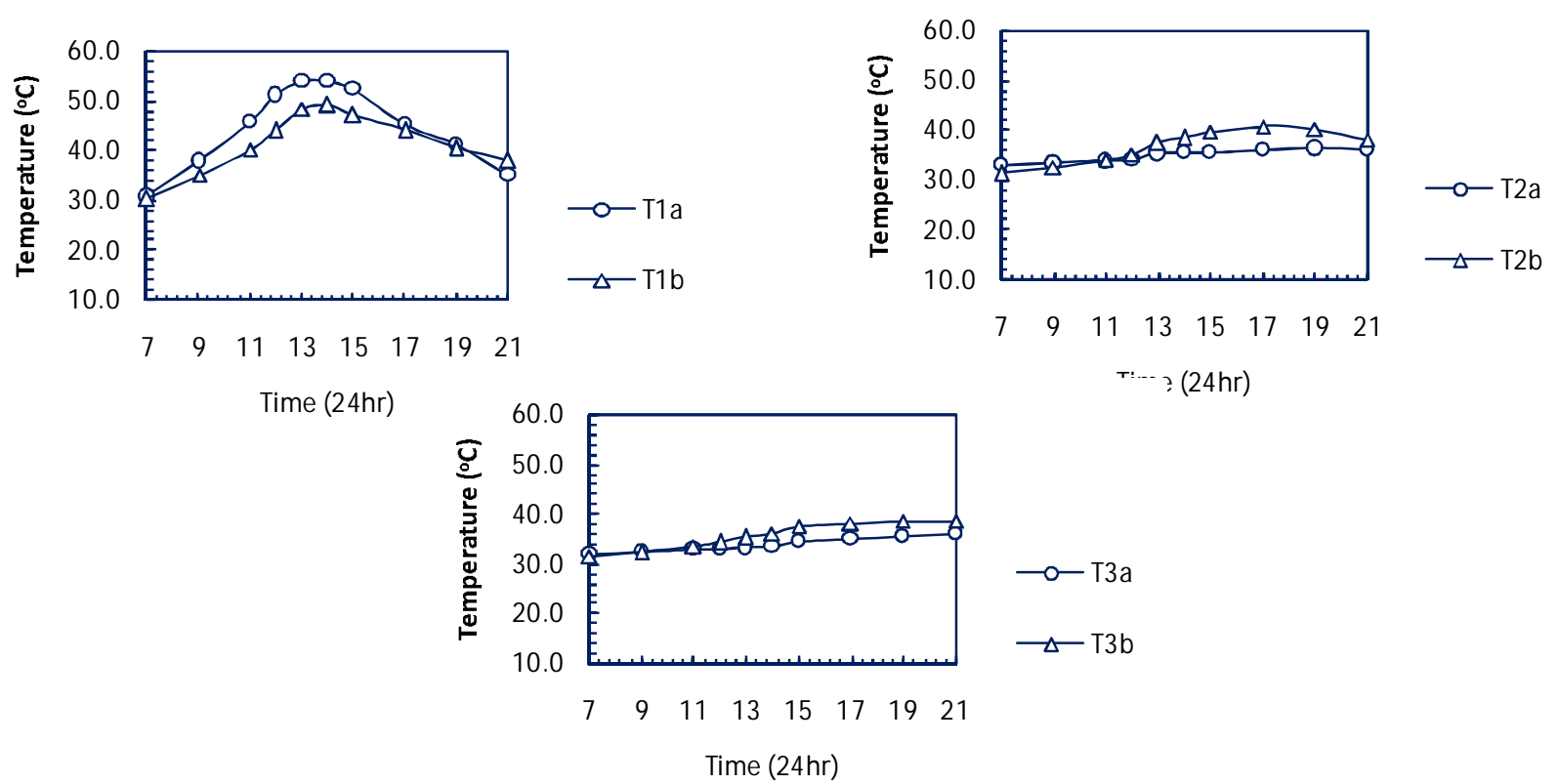

Figure (11): Comparison between mean temperature readings of model $\mathrm{A}$ and Model B for TB. 


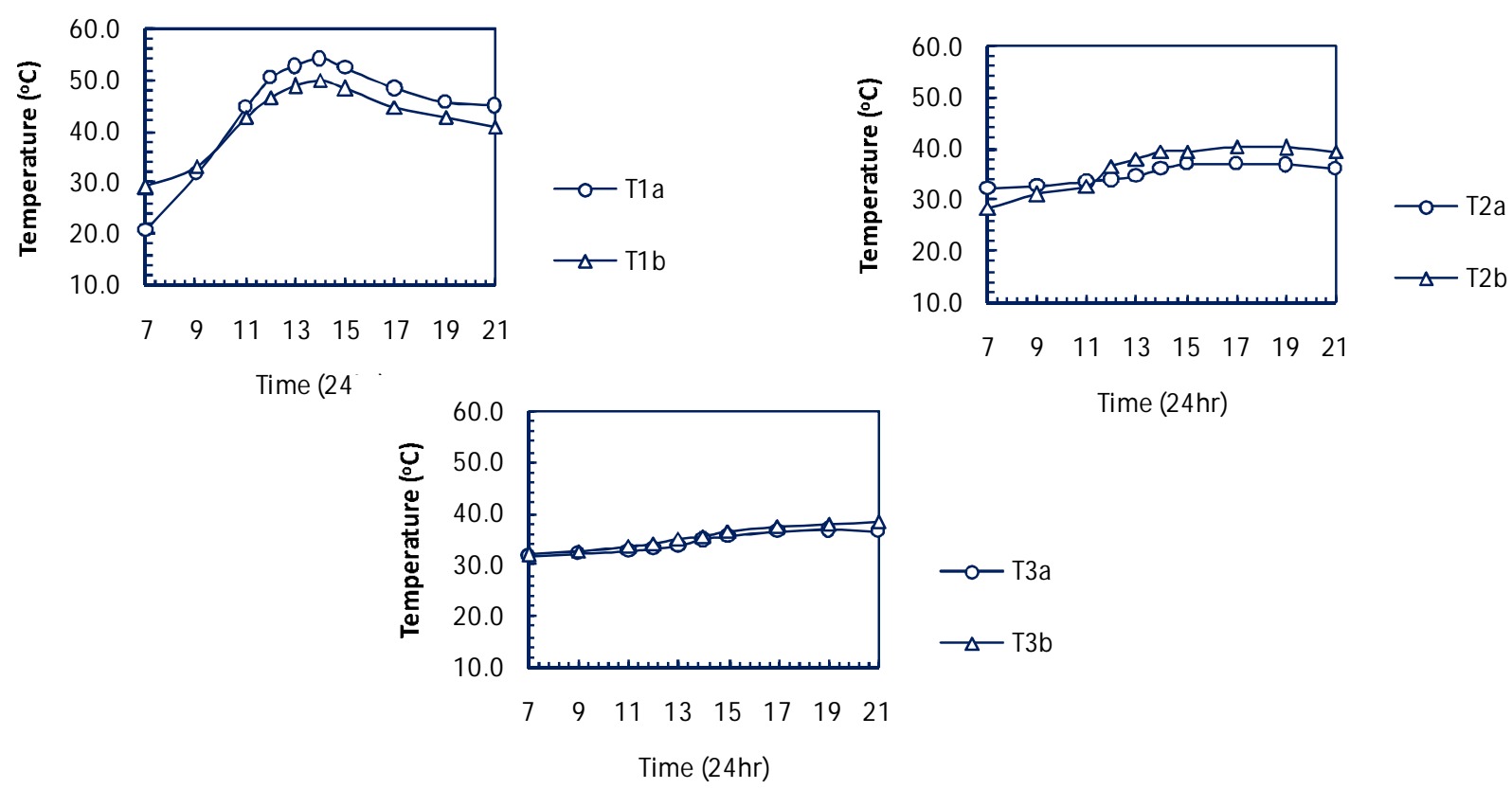

Figure (12): Comparison between mean temperature readings of model $A$ and Model B for PB.

\subsection{Compressive Strength:}

Group AC was found to carry a load of $5.23 \mathrm{kN}$, while a single can carried a load of $0.75 \mathrm{kN}$. The number of cans beneath one tile $(30 \times 30 \mathrm{~cm})$ consisted at least of fourteen cans, this means that one tile can carry a load of $10.5 \mathrm{kN}$. These results could be calculated roughly for one square meter, which is equal to be $100 \mathrm{kN} / \mathrm{m}^{2}$.

TB was found to withstand $10 \mathrm{kN} / \mathrm{m}^{2}$ according the Iraqi Standard Specifications No. 1441. PB was considered in this paper to carry the minimal compressive strength compared with the $\mathrm{AC}$ and the TB, table (3). From these results it can be concluded that AC withstand a load much higher than the TB and PB.

\subsection{Weight:}

The weight of any insulation material is considered to represent its dead load. Table (3) shows the weight of each insulation material for one square meter. Each can was weighted, the weight range was (20-27)g. It was also found that in order to cover an area of one square meter, a number of (255) cans were required, this will bring the total dead load to $(6.5) \mathrm{kg} / \mathrm{m}^{2}$.

Table(3): compressive strength and weight of the selected insulation materials.

\begin{tabular}{lcc}
\hline Insulation material & Compressive strength $\left(\mathrm{kN} / \mathrm{m}^{2}\right)$ & Weight $\left(\mathrm{kg} / \mathrm{m}^{2}\right)$ \\
$\mathrm{AC}$ & 100 & 6.5 \\
$\mathrm{~TB}$ & 10 & 20 \\
$\mathrm{~PB}$ & None & 1.0 \\
\hline
\end{tabular}




\subsection{Cost:}

The cost of any insulation material has the controlling rule for selection, the higher the cost, the better the insulation and the higher the construction cost. In this study, AC was found to meet the minimum cost requirements, since $\mathrm{AC}$ could be collected from Aluminum Recycling Agencies, beside the minimal construction cost. AC may also be bought directly from the factory for insulation use. The cost of AC is much lower than the cost of TB and the $\mathrm{PB}$

\section{Conclusions:}

The tested insulation materials were evaluated through models, AC showed a significant results. Experiments also showed that the cans are a good thermal insulation material and can withstand a considerable live and dead loads, in addition to the low construction cost and low dead weight. From practical side of view, these cans could be packed using nylon sheets with suitable dimensions $(100 \times 100 \mathrm{~cm}$ or $50 \times 50 \mathrm{~cm})$ for easy installation process beneath the floor's or ceiling's tiles. As it was stated before that the AC recycling rate is decreasing, the use of these cans is certainly will contribute in solving part of the environmental problems.

\section{References:}

[1] Akash Singh, Mohd. Alam Khan, Jahi Gaur and Grishma Gupta, "Thermal insulation of energy efficient buildings", 2007. http://en.scientificcommons.org/42406716

[2] The Aluminum Association, "Aluminum Industry Technology Roadmap", 2003. http://www1.eere.energy.gov/industry/aluminum/pdfs/al_roadmap.pdf

[3] Missouri Recycling Association, Recycling Guide, 2007. http://www.mora.org/publications/recycling_guide

[4] Mark E. Schlesinger, "Aluminum Recycling", Taylor and Francis Group, LLC, 2007.

[5] Marceau, Medgar L., Gajda, John, VanGeem, Martha G., Gentry, Thomas, and Nisbet, Michael A., "Partial Environmental Life Cycle Inventory of an Insulating Concrete Form House Compared to a Wood Frame House", R\&D Serial No. 2464, Portland Cement Association, Skokie, Illinois, 2000.

[6] Richard T. Bynum Jr., "Insulation Handbook", McGraw Hill, 2001.

[7] Wayne C. Turner and Steve Doty, "Energy Management Handbook", The Fairmont Press, INC, $6^{\text {th }}$ ed., 2007.

[8] M. Necati ÖziŞik, "Heat Transfer, A basic Approach", McGraw Hill, 1985.

[9] W. M. Rohsenow, J. P. Hartnett and Y. I. Cho, "Handbook of Heat Transfer", McGraw Hill, $3^{\text {rd }}$ ed., 1998. 